UDC 612.014.3+576.385.4

G. HAN, ${ }^{1}$ W. WEI, ${ }^{1}$ X. ZHANG,${ }^{2}$ ZH. LAI, ${ }^{1}$ and CH. CHEN ${ }^{1}$

\title{
EFFECTS OF TRANSDUCTION OF THE $b c l-2$ GENE AND OF NERVE GROWTH FACTOR ON APOPTOSIS OF CULTURED PC12 CELLS
}

\author{
Received 22.08.2013
}

We examined what effects are exerted by expression of the bcl-2 gene and by treatment with nerve growth factor (NGF) on the intensity of apoptosis in cultured pheochromocytoma cells (PC12 cells). Half of these cells were transduced with the $b c l-2$ gene using lentiviral plasmids, and the respective two groups were denoted as bcl-2-PC12 and control (c) PC12. Then the cells were incubated in a serum-free medium in six different modes. One group of c-PC12 cells was incubated in this medium with no additional agents added, another group was incubated with $1.0 \mathrm{mM} \mathrm{H}_{2} \mathrm{O}_{2}$, and the third group was incubated with both $1 \mathrm{mM} \mathrm{H}_{2} \mathrm{O}_{2}$ and $20 \mathrm{ng} / \mathrm{ml} \mathrm{NGF}$ (groups 1-3). Cells of the another triad were incubated under the same conditions, respectively, but these were $b c l-2-\mathrm{PC} 12$ cells (groups 4-6). The apoptosis rate in each group after 1-h-long incubation was measured using a flow cytometry method. A bicinchoninic acid (BCA) technique was used for estimation of expression of $\mathrm{Bcl}-2$ protein in the cultures. As was observed, the action of $\mathrm{H}_{2} \mathrm{O}_{2}$ significantly increased the apoptosis rate in both c-PC12 and bcl-2-PC12 samplings, while simultaneous action of NGF considerably attenuated such increases. At the same time, values of the apoptosis rate for $b c l-2-\mathrm{PC} 12$ cells were much smaller than the respective values for c-PC12 cells under all the three modes of incubation. $\mathrm{In}_{2} \mathrm{O}_{2}$-treated cultures, the amount of $\mathrm{Bcl}-2$ protein dropped, while the treatment with NGF counteracted such shifts. The content of this protein in the $b c l-2-\mathrm{PC} 12$ groups was much higher than in the c-PC12 groups. Thus, transduction with the $b c l-2$ gene significantly inhibits apoptosis in cultured PC12 cells, and a combined influence of expression of this gene and treatment with NGF produces a synergistic effect.

KEYWORDS: pheochromocytoma PC12 cells, $b c l-2$ gene, transduction, lentiviral plasmids, nerve growth factor (NGF), apoptosis.

\section{INTRODUCTION}

Spinal cord injury (SCI) in most cases causes dramatic sensory, motor, and autonomic deficits. The patients may get paraplegia or quadriplegia depending on the region of spinal lesion [1]. Because there is limited or no neurological recovery once SCI occurred, the latter creates great socioeconomic problems related to serious and stable disability of SCI patients and to efforts and costs involved in the diagnostics, treatment, and rehabilitation of this contingent [2].

Nerve growth factor (NGF), a prototypic member of the neurotrophin family, was initially recognized as a pro-survival and pro-differentiation factor for sensory

\footnotetext{
${ }^{1}$ Hangzhou Red Cross Hospital, Hangzhou, China.

${ }^{2}$ Department of Cell Biology and Medical Genetics, National Education Base for Basic Medical Sciences, Institute of Cell Biology, Zhejiang University School of Medicine, Hangzhou, China.

Correspondence should be addressed to $\mathrm{Ch}$. Chen

(e-mail: zhitree@hotmail.com).
}

and sympathetic neurons [3]. It can play a positive role in the recovery of nerve functions after injury [4]. Among pathological changes in the injured spinal cord, strong intensification of apoptosis occupies one of the crucial positions. An anti-apoptotic protein from B-cell CLL/lymphoma 2, Bcl-2, was shown to be a powerful inhibitor of apoptotic and necrotic cell death [5]. Chen et al [6] found that the proto-oncogene $b c l-2$ plays a critical role in neuronal morphogenesis in the CNS of mammals.

Our work was to examing figure out of how expression of the $b c l-2$ gene and treatment with NGF affect apoptotic cell death in a model system, cultured pheochromocytoma (PC12) cells.

\section{METHODS}

In our study, a rat pheochromocytoma cloned cell line 
(PC12 cells) was used. Samples of these cells were purchased from the Shanghai Institute of Cell Bank (China). Cultured PC12 cells have been recognized to be a suitable model for certain directions of neuroscience research [7]. These cells are known to be rather close to the nerve cells in a few properties; under definite conditions, such cells can be differentiated into neuron-like units.

Lentiviral plasmids carrying the $b c l-2$ gene and the analogous plasmids that did not carry this gene were purchased from the Shanghai Jima Biotech Company (China).

PC12 Cell Culturing and Lentiviral Plasmid Transduction. PC12 cells were conserved in a liquid nitrogen tank. Cells were recovered and incubated at $37{ }^{\circ} \mathrm{C}$ in an atmosphere of air enriched with $\mathrm{CO}_{2}$ to 5\%. A Dulbecco's modified Eagle's medium (DMEM; Gibco BRL, USA) supplemented with 10\% heatinactivated fetal bovine serum (FBS), 5\% heatinactivated horse serum (HS, both from Hyclone, USA), and penicillin-streptomycin was used. Cells were reseeded for two or three generations to be fully restored.

The PC12 cells were seeded in the above DMEM complete medium for transduction with $b c l-2$ lentiviral plasmids and lentiviral plasmids with no $b c l-2$ at a multiplicity of infection (MOI) of 100 . The cells successfully transduced with $b c l-2$ lentiviral plasmids

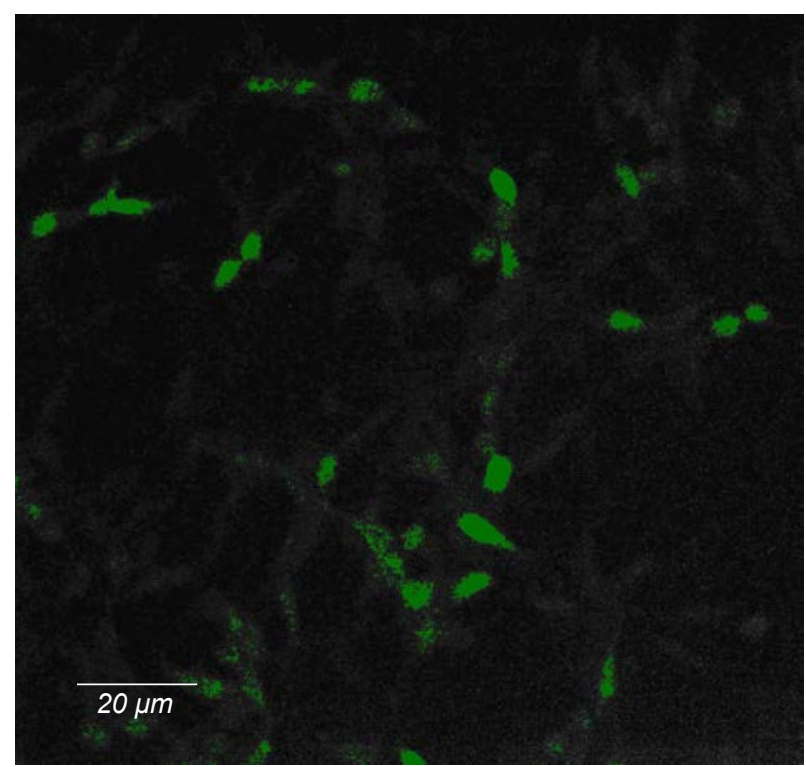

F i g. 1. PC12 cells successfully transduced by $b c l$-2-carrying lentiviral plasmids and observed under an inverted fluorescence microscope.

Р и с. 1. Клітини РС12 після успішної трансдукції з використанням лентівірусних плазмід, що несуть ген $b c l-2$. are denoted below as bcl-2-PC12, while those transduced with no $b c l-2$ lentiviral plasmids are denoted as control, c-PC12 (Figs. 1 and 2). Then, the cells were cultured on collagen-coated 6 -well plates $\left(10^{5}\right.$ cells per well) and incubated for $1 \mathrm{~h}$ at $37^{\circ} \mathrm{C}$ in a serum-free medium (Invitrogen, USA) in six different ways denoted as groups 1-6. Group 1 served as an intact control; these were c-PC12 cells (with no induced expression of the $b c l-2$ gene) that were not subjected to the action of any additional factor. In group 2, c-PC12 cells were incubated in a medium with $1 \mathrm{mM} \mathrm{H}_{2} \mathrm{O}_{2}$ added. Hydrogen peroxide $\left(\mathrm{H}_{2} \mathrm{O}_{2}\right)$ is a key signaling molecule that intensifies apoptosis by inducing oxidative stress via free oxygen radicals. In group 3, c-PC12 cells were subjected to a combined action of $1 \mathrm{mM} \mathrm{H}_{2} \mathrm{O}_{2}$ and NGF (final concentration $20 \mathrm{ng} / \mathrm{ml}$ ). Another triad, groups 4-6, was incubated under conditions similar to those for groups 1-3, respectively, but these were transfected PC12 cells (group 4, bcl-2-PC12; group 5, bcl-2-PC12+ $+\mathrm{H}_{2} \mathrm{O}_{2}$, and group 6, bcl-2-PC12 $+\mathrm{H}_{2} \mathrm{O}_{2}+\mathrm{NGF}$ ).

Apoptosis Assessment by Flow Cytometry. The cells were trypsinized, centrifuged at $1200 \mathrm{~min}^{-1}$ for $5 \mathrm{~min}$, and collected. Apoptosis was evaluated using the Alexa Fluor ${ }^{\circledR} 488$ annexin V/Dead Cell Apoptosis Kit (Invitrogen; USA).The cells were resuspended in $100 \mu l$ of annexin-binding buffer after washed twice with cold $\left(4^{\circ} \mathrm{C}\right)$ phosphate-buffered saline (PBS). According to the apoptosis detection kit reference, $5 \mu$ of annexin V-fluorescein isothiocyanate (FITC) and $1 \mu \mathrm{l}$ of a propidium iodide (PI) solution $(100 \mu \mathrm{g} / \mathrm{ml})$ were added to each sample. After incubated for $15 \mathrm{~min}$ at $20^{\circ} \mathrm{C}, 400 \mu \mathrm{l}$

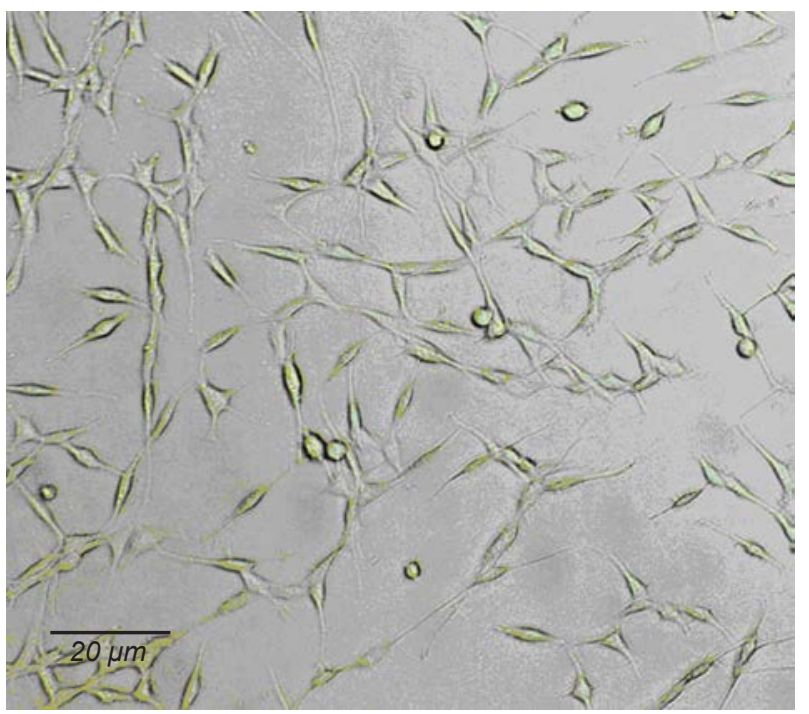

F i g. 2. PC12 cells before transfection.

Р и с. 2. Клітини РС12 перед трансфекцією. 
of annexin-binding buffer was added to each suspension, which was analyzed by flow cytometry (BD Biosciences, USA). Annexin V-FITC-negative and PI-negative cells were considered living cells. Cells positive with respect to annexin V-FITC but negative for PI were classified as being in the stage of early apoptosis. Cells positive for both annexin V-FITC and PI were considered to be in the stage of late apoptosis, while cells positive with respect to PI were considered to be in necrosis. Normalized numbers (\%) of the cells belonging to the above groups were calculated. The analysis was performed using FACSDiva software (BD Biosciences, USA).

Assessment of Expression of Bcl-2 Protein. All groups of the cells were cultured for $24 \mathrm{~h}$. After treatment, cells were harvested, washed once with PBS, and lysed with phenylmethanesulfonyl fluoride (PMSF) at $4{ }^{\circ} \mathrm{C}$ for $30 \mathrm{~min}$. The protein produced due to $b c l-2$ gene expression was obtained after 10-minlong centrifugation at $12,000 \mathrm{~min}^{-1}$ at $4{ }^{\circ} \mathrm{C}$. The amount of this protein was determined using the bicinchoninic acid (BCA) method.

Statistical Analysis. Statistical analysis was performed using SPSS13.0 (SPSS, USA). The apoptosis rates in the groups were compared with the nonparametric Mann-Whitney $U$ test. Protein concentrations followed a normal distribution, so the Student's $t$-test was used for intergroup comparisons. Numerical data are presented below as means \pm s.e.m., unless stated otherwise. The differences with $P<0.05$ were considered statistically significant.

\section{RESULTS}

Effects of Expression of the bcl-2 Gene and Treatment with NGF on the Apoptosis rate of Cultured PC12

Cells. As was found, the rate of apoptosis in group 1 (c-PC12 cells incubated under above-described conditions with no additional influences) was equal to $15.63 \%$ on average; this value was taken as $100 \%$ in comparison with other groups. Under the influence of $1 \mathrm{mM} \mathrm{H} \mathrm{O}_{2}$, the level of apoptosis in group 2 was significantly higher than that in group 1 (by $68.8 \%$, on average). The above index in group 3 (c-PC12 $+\mathrm{H}_{2} \mathrm{O}_{2}+$ + NGF) noticeably exceeded the respective value in the intact control group 1 (by $28.2 \%$ ), but, at the same
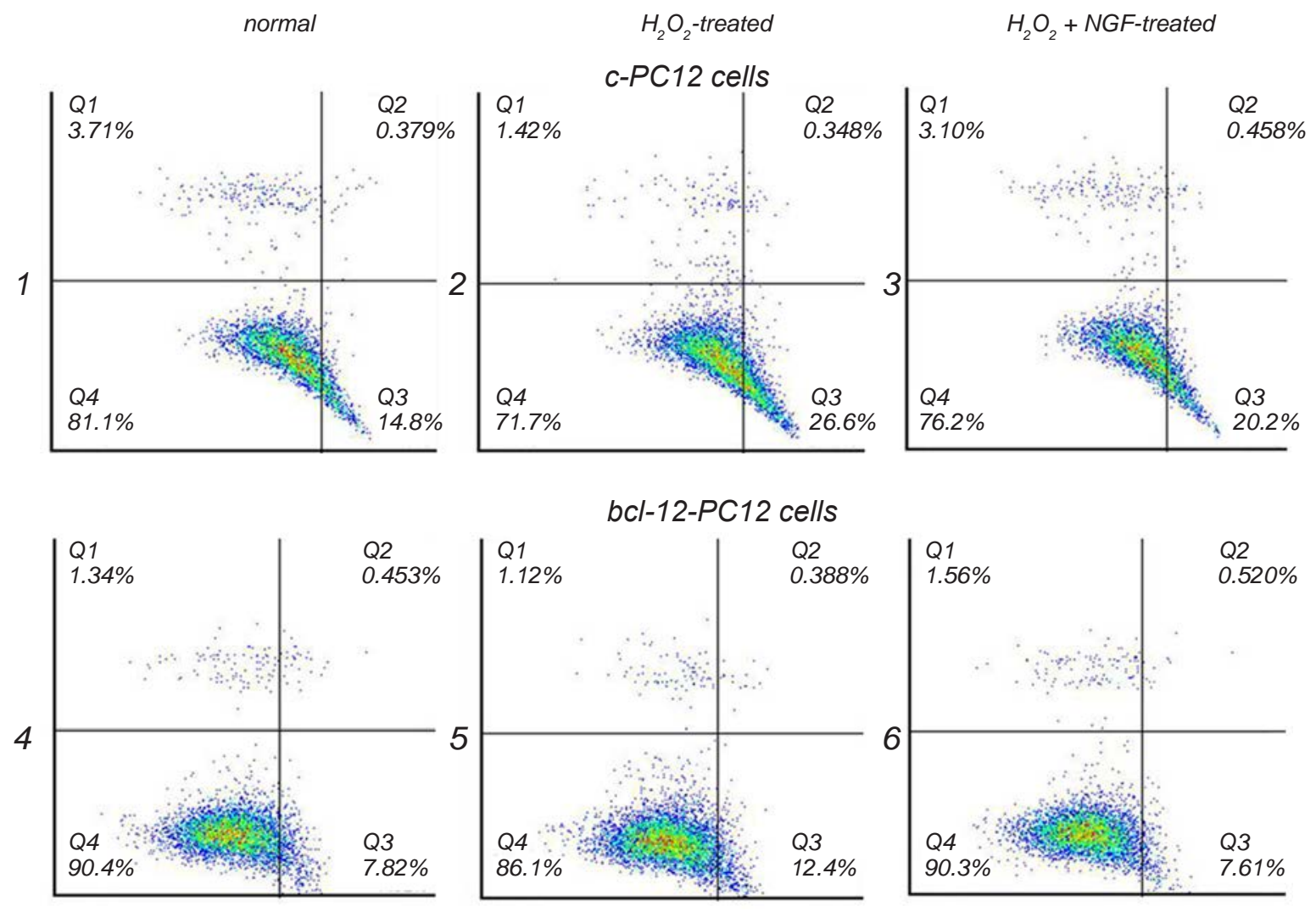

F i g. 3. Estimation of the apoptosis rate using flow cytometry. 1-6) Groups of PC12 cells incubated under different conditions.

Р и с. 3. Оцінка ступеню апоптозу з використанням флоуцитометрії. 


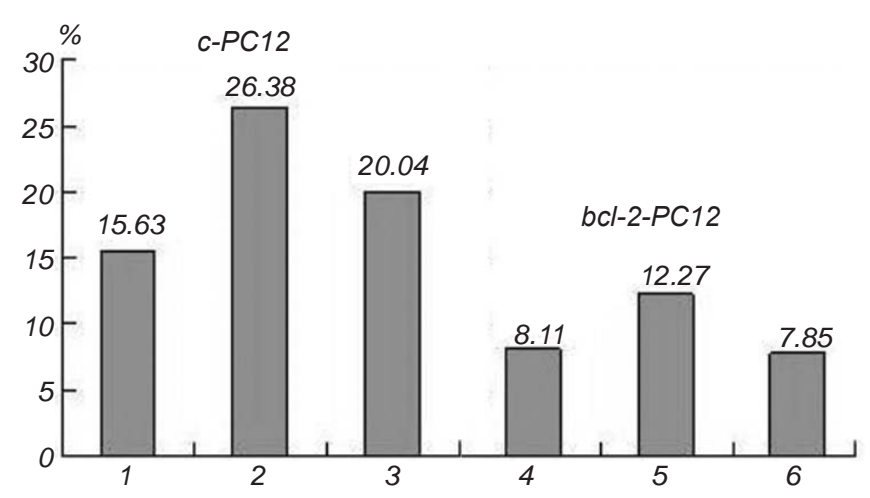

F i g. 4. Apoptosis rates (\%) in the groups of PC12 cells (1-6) incubated under different conditions.

Р и с. 4. Ступінь апоптозу (\%) у групах клітин РС12, інкубованих у різних умовах (1-6).

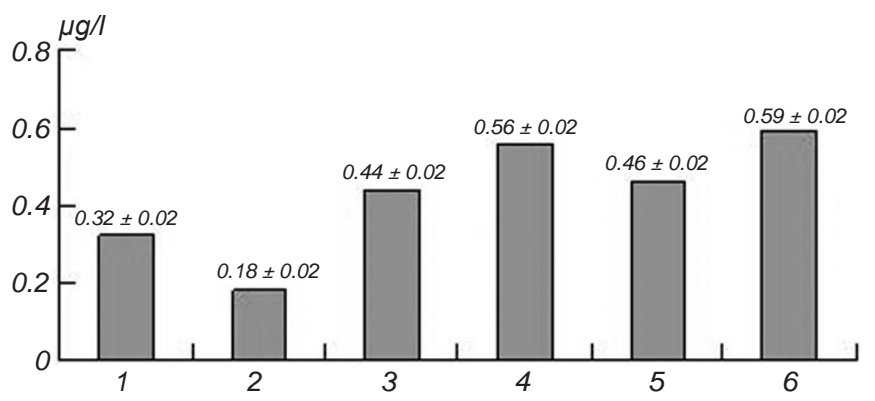

F i g. 5. Concentrations $(\mu \mathrm{g} / \mathrm{l})$ of $\mathrm{Bcl}-2$ protein expressed in the groups of PC12 cells (1-6) incubated under different conditions.

P и с. 5. Концентрації білка Bcl-2 (мкг/л), експресованого в групах клітин РС12, котрі інкубувалися в різних умовах.

time, it was much lower than that in group 2 (c-PC12+ $+\mathrm{H}_{2} \mathrm{O}_{2}$ ). If we take the apoptosis rat in group 2 as $100 \%$, a decrement of this index related to NGF action in group 3 corresponded to $24.0 \%$.

In groups 4-6, the apoptosis rates for PC12 cells successfully transfected with $b c l-2$ gene were significantly lower than those in the corresponding groups 1-3 (PC12 cells with no transfected $b c l-2$ gene). This index in group 4 was about two times smaller than that in group 1 (by $48.1 \%, u=2.16, P<0.05$ ). In group 5 (bcl-2-PC12 cells subjected to isolated action of $1 \mathrm{mM} \mathrm{H}_{2} \mathrm{O}_{2}$ ), the apoptosis rate was noticeably greater than in group 4 . At the same time, this index was significantly (more than two times) smaller than that in the corresponding group 2 (c-PC12+ $\mathrm{H}_{2} \mathrm{O}_{2}$, $u=2.38, P<0.05)$. The analyzed index in group 6 (bcl-2-PC12+ $\left.\mathrm{H}_{2} \mathrm{O}_{2}+\mathrm{NGF}\right)$ was much lower than that in group 5; this value was nearly equal to that in group 4 and 2.5 times smaller than the respective index in group 3 (c-PC12 $+\mathrm{H}_{2} \mathrm{O}_{2}+\mathrm{NGF} ; u=2.83, P<0.05$ ).

Effects of Transduction with the bcl-2 Gene and Treatment with NGF on the Amount of Bcl-2 Protein in Cultured PC12 Cells. The mean amount of the mentioned protein in group 1 (c-PC12 cells with no additional influence) was $0.32 \pm 0.02 \mu \mathrm{g} / 1$. The addition of $1 \mathrm{mM} \mathrm{H}_{2} \mathrm{O}_{2}$ to the cultured medium resulted in a dramatic drop in the concentration of this protein (by $43.7 \%$ as compared with group 1). At the same time, when $\mathrm{H}_{2} \mathrm{O}_{2}$ and $\mathrm{NGF}$ influenced cultured c-PC12 cells in group 3 simultaneously, the mean amount of Bcl-2 protein was much greater than that in group 2 and even exceeded the respective index in the "intact" group 1 (by $37.5 \%$, on average).

In cultured PC12 cells transfected with the $b c l-2$ gene (groups 4-6), the amounts of $\mathrm{Bcl}-2$ protein significantly exceeded the corresponding indices in the respective groups of c-PC12 cell. In group 4, the mean value was, on average, $175 \%$ of that in group 1 . In group 5 , the value was $256 \%$ of that in group $2(t=2.75, P<0.05$, both groups were treated with $\mathrm{H}_{2} \mathrm{O}_{2}$ ). In group 6 , the $\mathrm{Bcl}-2$ content was $134 \%$ of the value in group $3(t=2.23, P<0.05$; as was mentioned, these groups were simultaneously influenced by $\mathrm{H}_{2} \mathrm{O}_{2}$ and NGF). Thus, transduction with the $b c l-2$ gene significantly increases the amount of the respective protein, and a combined influence of such transduction and treatment with NGF produces a synergistic effect.

\section{DISCUSSION}

At present, major treatment of SCI includes application of neuroprotective agents used to prevent damage development within the acute phase. This therapy includes the improvement of the oxygenation ability, scavenging of free radicals, and correction of biochemical disorders. Within the sub-acute and late phases, neurotrophic factor (NTF) is used to prevent nutritional deficiency in neurons. This agent can also promote axonal growth. There are other methods to intensify long-distance regeneration ability of the axons, such as neuronal transplantation associated with genetic-engineering cell import and applications of antibody proteins associated with the myelination process. Unfortunately, all these techniques are at present characterized by insufficient efficacies.

It has been reported that $\mathrm{NGF}$, the first representative of typical neurotrophic factors that was described and studied, exerts certain positive effects on the development of the nervous system, functional 
maintenance, and reparation [1-3]. It was shown to facilitate regeneration and reparation of impaired neurons. Major mechanisms of the NGF function are as follows: (i) inhibition of the release of toxic amino acids; (ii) inhibition of calcium overloading; (iii) inhibition of the release of superoxide radicals, and (iv) inhibition of the apoptosis process.

Gene therapy is one of the rapidly developing approaches in the field of biomedical research. Expression of the proto-oncogene $b c l-2$ was shown to be a powerful anti-apoptotic factor. Chen et al. [6] found that $\mathrm{Bcl}-2$ protein, the product of the $\mathrm{bcl}-2$ gene can promote regeneration in the severed mammalian CNS, in particular regeneration of axons after SCI. Such findings provide a theoretical basis for introduction of gene therapy in pathophysiological situations needing neural regeneration [6]. Takahashi et al. [8] found that injection of DNA plasmids carrying the $b c l-2$ gene can reduce neuronal apoptosis after SCI [8]. There are also other observations that the $b c l-2$ gene can exert a significant protective effect with respect to neuronal apoptosis caused by injury under both in vivo and in vitro conditions [9-11].

We tested the effects provided by transduction with the $b c l-2$ gene and by application of NGF in an in vitro model system, cultured rat pheochromocytoma PC12 cells. These cells are not neural units in a strict meaning of the term, but this cell line possesses certain properties rather similar to those of neurons (see above). These cells can be cultured for rather long time intervals, the technology of culturing is standardized, and the influences exerted by different factors on the viability of such cells can be estimated much more easily and accurately than in the in vivo experiments.

Our measurements showed that transfection with the $b c l-2$ gene provides significant intensification of the synthesis of protein Bcl-2 in cultured PC12 cells. Under conditions of our experiments, the amounts of this protein in groups 4-6 exceeded the control index in group 1 of c-PC12 cells (sham-transfected) by $44-84 \%$ (Fig. 5). As is known, Bcl-2 is a powerful inhibitory factor limiting apoptotic and necrotic cell death [5]. So, increased levels of Bcl-2 in cultured groups 4-6 clearly correlate with significantly lower, than in the corresponding groups 1-3 (c-PC12 cells), rates of apoptosis.

On the other side, NGF also demonstrated in our experiments clear anto-apoptotic properties in our experiments. In c-PC12 cells of group 2, the addition of $1 \mathrm{mM} \mathrm{H}_{2} \mathrm{O}_{2}$ to the incubation medium increased the apoptosis rate by nearly $70 \%$. At the same time, when NGF was added to the above medium (group 3), the respective increment shortened to less than $30 \%$. Even more impressive effects of the NGF addition to the medium were found in bcl-2-PC12 samplings. The action of $1 \mathrm{mM} \mathrm{H}_{2} \mathrm{O}_{2}$ increased the apoptosis rate in group 5 by nearly $80 \%$. In group 6 , NGF practically completely eliminated the negative effect of $\mathrm{H}_{2} \mathrm{O}_{2}$. The mean apoptosis rate in this group was found to be even somewhat lower than in the intact control group 1 (Fig. 4). Thus, we conclude that a combined action of Bcl-2 protein and NGF provide a clear synergistic effect.

Of course, at present it is too early to believe that a combination of gene therapy and action of the agents intensifying recovery and growth processes in nerve elements is ready to be directly applied in clinics. Nonetheless, our findings together with the results of other researchers allow us to think that such combinations look as promising approaches in the treatment of the consequences of CNS traumas and of SCI in particular. This, of course, implies the need of detailed studies directed toward adequate interpretation of the mechanisms of such combined effects and development of the most expedient modes of the action of the respective agents.

\section{Г. Хан ${ }^{1}$, У. Уей, ${ }^{1}$ Кс. Жанг, ${ }^{2}$ Ж. Лай, ${ }^{1}$ Ч. Чен ${ }^{1}$}

ВПЛИВИ ТРАНСДУКЦІЇ ГЕНА $b c l-2$ ТА ДІЇ НЕРВОВОГО ФАКТОРА РОСТУ НА АПОПТОЗ КУЛЬТИВОВАНИХ КЛІТИН РС12

1 Лікарня Червоного Хеста, Ханчжоу (Китай).

${ }^{2}$ Національна освітня база фундаментальних медичних наук Інституту клітинної біології Чжеджанського Медичного Університету, Ханчжоу (Китай).

P е 3 ю м е

Ми досліджували впливи експресії гена $b c l$-2 та дії нервового фактора росту (NGF) на інтенсивність апоптозу культивованих клітин феохромоцитоми (РС12). У половину таких клітин був трансдукований ген $b c l-2$; відповідні дві групи зразків були позначені як $b c l-2$-PC12 та контрольні (c-РС12). Потім шість груп клітин інкубували в безсироватковому середовищі в різних умовах. Перша група клітин с-РС12 інкубувалася без дії будь-яких додаткових агентів, друга група - 3 додаванням 1 мМ $\mathrm{H}_{2} \mathrm{O}_{2}$, а третя в присутності як 1 мM H $\mathrm{O}_{2}$, так і 20 нг/мл NGF. Клітини трьох інших груп (4-6) інкубували в тих самих умовах, 
але це були клітини $b c l-2-\mathrm{PC} 12$. Ступінь апоптозу в кожній групі після одногодинної інкубації вимірювали з використанням методу флоуцитометрії. Методику з використанням біцинхонінової кислоти застосовували для оцінки експресії білка Bcl-2 в культурах. Як було виявлено, дія $\mathrm{H}_{2} \mathrm{O}_{2}$ істотно збільшувала ступінь апоптозу в зразках як с-РС 12 , так і bcl-2-PC12, але одночасна дія NGF помітно зменшувала таке зростання. В той же час інтенсивності апоптозу клітин $b c l-2$-РC12 були значно меншими, ніж відповідні значення у клітин с-РС12 при всіх трьох режимах інкубації. В культурах, підданих впливу $\mathrm{H}_{2} \mathrm{O}_{2}$, кількість протеїну Bcl-2 була зменшеною, тоді як вплив NGF протидіяв таким зрушенням. Вміст згаданого протеїну в групах $b c l-2$-PC12 був значно вищим, ніж у групах с-РC12. Отже, трансдукція гена $b c l$ 2 істотно гальмує апоптоз культивованих клітин РC12, а комбінований вплив експресії цього гена та аплікації NGF забезпечує сінергічні ефекти.

\section{REFERENCES}

1. R. Gupta, M. E. Bathen, J. S. Smith, et al., "Advances in the management of spinal cord injury," J. Am. Acad. Orthop. Surg., 18, No. 4, 210-222 (2010).

2. I. G. Fiedler, P. W. Laud, D. J. Maiman, et al., "Economics of managed care in spinal cord injury," Arch. Phys. Med. Rehabil., 80, No. 11, 1441-1449 (1999).

3. A. Caporali and C. Emanueli, "Cardiovascular actions of neurotrophins," Physiol. Rev., 89, 279-308 (2009).

4. C. Johanson, E. Stopa, A. Baird, et al., "Traumatic brain injury and recovery mechanisms: peptide modulation of periventricular neurogenic regions by the choroid plexus-CSF nexus," J. Neural. Transm., 118, 115-133 (2011).

5. S. T. DeKosky, K. M. Taffe, E. E. Abrahamson, et al., "Time course analysis of hippocampal nerve growth factor and antioxidant enzyme activity following lateral controlled cortical impact brain injury in the rat," J. Neurotrauma, 21, 491-500 (2004).

6. G. Chen and H. K. Manji, "The extracellular signal-regulated kinase pathway: an emerging promising target for mood stabilizers," Current Opin. Psychiat., 19, 313-323 (2006).

7. M. Shirane and K. I. Nakayama, "Protrudin induces neurite formation by directional membrane traicking," Science, 314, No. 5800, 818-821 (2006).

8. K. Takahashi, E. Schwarz, C. Ljubetic, et al., "DNA plasmid that codes for human Bcl-2 gene preserves axotomized Clarke's nucleus neurons and reduces atrophy after spinal cord hemisection in adult rats," J. Comp. Neurol., 404, 2, 159-171 (1999).

9. H. Zhao, M. A. Yenari, D. Cheng, et al., "Bcl-2 overexpression protects against neuron loss within the ischemic margin following experimental stroke and inhibits cytochrome translocation and caspase-3 activity," J. Neurochem., 85, No. 9, 1026-1036 (2003).

10. S. Yamashita, S. Mita, S. Kato, et al., "Bcl-2 expression using retrograde transport of adenoviral vectors inhibits cytochrome c-release and caspase- 1 activation in motor neurons of mutant superoxide dismutase 1(G93A) transgenic mice," Neurosci. Lett., 350, No. 1, 17-20 (2003).

11. Y. Yukawa, J. Lou, N. Fukui, et al., "Optimal treatment timing to attenuate neuronal apoptosis via Bcl-2 gene transfer in vitro and in vivo," J. Neurotrauma, 19, No. 8, 1091-1103 (2002). 